\title{
Comparison of the Policies of Israel's Labor Party and the Likud on Palestinian Refugee*
}

\author{
Song NIU \\ Shanghai International Studies University, Shanghai, China \\ Xuan ZHANG \\ Shanghai International Studies University, Shanghai, China
}

\begin{abstract}
Since its origin in the first Middle East War in 1948, the Palestinian refugee problem has not been properly resolved. Over the years, the key stakeholder Israel has put forward a variety of plans and countermeasures on refugee issues in multilateral and bilateral diplomatic stages. Researches on these policies of Israel on Palestinian refugees are crucial for solving this problem. The right wing and the left wing of political parties in Israel-Israel's Likud and Labor Party had the longest and most influential rulings in the country. The refugee policies they have taken during their administrations have an impact on the development of the peace process in the Middle East, and also play a direct role in solving the problem of refugees. Through the analysis on refugee policies of the ruling party in various stages of the evolvement of the Arab-Israeli conflict, we can compare the Labor Party's and the Likud Party's policies for Palestinian refugees, and found that the policies of these two parties are consistent and similar on the issue of refugees, for example, neither of them recognize the responsibility of Israel on refugees, and they both denied the "right to return" of refugees, etc. In terms of the specific implementation of the policies, there are differences between them: the Likud Party was significantly tougher than the Labor Party. Both Labor and Likud is being affected by domestic and international factors, such as homeland security, the Jewish state property, political system, Jewish mentality and the support of the United States and other factors, so their policies are consistent; however, due to different historical factions, different voter groups, and national interests as well as the interests of the parties in different periods, the two parties have different refugee policies.
\end{abstract}

Keywords: Palestinian refugees, Israeli politics, the Labor Party, the Likud Party, policy comparison

\section{Introduction}

The conflict between Israel and Palestine has last for a century to date since the initial Arab-Jewish conflict. From the five Middle East wars to the rocket attacks, terrorist attacks and air strikes, which are still common nowadays, the outbreak of each conflict will directly lead to a large number of people who lost their homes and became refugees. Now a large number of refugees in Syria have been displaced in turmoil, forming a great challenge on social stability for the surrounding countries and the European community that

\footnotetext{
${ }^{*}$ This article is financed by the National Social Science Fund of China (13CZJ017), the Shanghai International Studies University Research Team "Regional Cooperation between East Asia and Middle East in the New Era", and Key Research Institute in Universities (16JJDGJW012).

Song NIU, Ph.D., Associate Professor, Middle East Studies Institute, Shanghai International Studies University.

Xuan ZHANG, postgraduate, Middle East Studies Institute, Shanghai International Studies University.
} 
accommodates refugees, and the refugee problem has once again risen to be a hot topic. However, in fact, Palestinian refugees have far outnumbered the refugees in Syria; the impact on the surrounding countries caused by the refugees in the 68 years is not inferior to the pressure that Europe is facing today, and these refugees also have to face a new round of unrest in the Middle East during their diaspora process, such as a new round of attacks on the Palestinian refugees due to the outbreak of the crisis in Syria. A total of about 529,000 Palestinian refugees were living in Syria before the civil war (Wang, 2015, p. 84), after the outbreak of Syrian war, these refugees had to re-displace and fled their homes.

As the world's largest refugee group that has the longest diaspora and the largest scale (United Nations High Commissioner for Refugees, 2014; UNRWA, n.d. $)^{1}$, Palestinian refugees have existed for 68 years since the first Middle East War, and in the process of exile, they have evolved into the fourth generation of refugees through natural reproduction. The United Nations Relief and Works Agency for Palestine Refugees in the Near East (UNRWA) defines Palestinian refugees as, "persons whose normal place of residence was Palestine during the period June 1, 1946 to May 15, 1948, and who lost both home and means of livelihood as a result of the 1948 conflict" (UNRWA, n.d.). The Palestinian refugees mentioned in this article basically refer to those meet the definition of UNRWA, and the refugees due to the conflict between Palestine and Israel after 1948 are also included.

\section{The Palestinian Refugee Policies of the Labor Party and the Likud}

In the history of Arab-Israeli conflict, both the Labor Party and the Likud have made outstanding contribution to the maintenance of Israel's national security interests; they also share universality and continuity in the Palestinian refugee policies. But because of the differences in the parties' guiding ideology, the interests of voters, the domestic and foreign environment and so on, the refugee policies of the two parties are different.

From 1948 to 1977, the Labor Party dominated the Israeli politics. After the first Middle East War, although Israel rejected the UN Mediation Commissioner's request about allowing the return of refugees and being admitted to the refugees' return right, during this period, Israel still made diplomatic efforts to solve the refugee problem. At the 1949 Lausanne Conference, Israel's proposal to settle 200,000-250,000 refugees in exchange for Gaza's jurisdiction was rejected by Egypt. On August 3, Israel's "100,000 Refugees Offer" was rejected (Xu, 1998, p. 89). In 1953, the Compensation Committee under the Israeli cabinet proposed to donate $\$ 1$ billion to the International Foundation to sponsor the re-settlement of refugees in Arab state (Maslha, 1996), but it was again rejected by Arab states. In the indirect negotiations between Egypt and Israel in 1955, Ben Gurion put forward that Israel should not be responsible for the refugees, but it is possible for Israel to allow refugees and their relatives for a "family reunion".

After the Six Day War in 1967, Israel announced on July to allow the return of refugees due to the conflict, but these refugees were strictly defined: Only those that fled away from the West Bank from June 5 to July 4 , 1967, submitted the application form by themselves and gained approval by Israel can return to Israel before August 31, 1967. As of September 1, a total of 14,000 Palestinian refugees actually returned to Israel.

During the 1977 election, the Likud won over the Labor Party for the first time and gained the ruling throne. In 1978, after bilateral negotiations between Egypt and Israel, Israel announced in a statement that,

\footnotetext{
1 As of early October 2015, the War had resulted in 4,185,302 refugees in Syria, and Palestinian refugees that registered in United Nations Relief and Works Agency for Palestine Refugees in the Near East (UNRWA) were as many as 5.3 million.
} 


\begin{abstract}
We have rejected in this matter of the refugees first of all the view that the right to choose between repatriation and compensation is the refugees' exclusively. We have stated that Israel has at no time agreed to this view. That is on the question of choice. But we did not reject the fact that the need for compensation does exist-on the contrary we supported a suggestion in solving the refugee issue-we agreed that in part they should settle in those countries which they inhabit now. (Israel Ministry of Foreign Affairs, 1978)
\end{abstract}

In 1984, after the coalition of Likud and the Labor Party won the election, they carried out the bipartisan ruling by taking turns to appoint Prime Ministers. In order to change the situation of Palestinian refugees in Arab, in May 1991, the Israeli government called on the international community to dissolve the refugee camps in Judea and Samaria and the Gaza Strip, in order to improve the living conditions of the refugees and work on their resettlement. Israel would promote this action as a partner (Israel Ministry of Foreign Affairs, 1972).

In 1992, the Labor Party came to power; it pursued a more flexible policy in the Arab Israeli negotiations. On the issue of refugees, the Labor Party "supported the principle of separation of Israelis and Palestinians, but refused refugees to return to their homes" (Ye, 1998, p. 24). The Labor government in November 1992 released the "The Multilateral Talks: Structure and Progress Update", which said that Israel has offered to participate in wide-scale projects ranging from the total reintegration of the refugees in the host countries and the administered territories, leading to the eventual dismantlement of the camps throughout the region, to any partial solution that would alleviate the plight of the refugees and improve the quality of life in the camps such as promoting vocational training, improving communications, transportation, and service infrastructure and so on (Israel Ministry of Foreign Affairs, 1992a). In August 1993, the Israeli government led by the Labor Party signed the "Declaration of Principles on Interim Self-Government Arrangements" with Palestine, which included the refugee issues in the final status negotiations and agreed to solve the refugee problem occurring in 1948 through bilateral negotiations between Palestine and Israel, and to resolve the refugee problems after 1967 through the Quartet talks among Israel, Palestine, Egypt, and Jordan. At the same time, Israel would approve 2000 refugees' application for "family reunion" each year, and grant 6,000 Arabs in the West Bank and Gaza Strip with the permanent resident status. On September 28, 1995, Palestine and Israel signed an agreement on the implementation of the Declaration of Principles in Washington DC, which reaffirmed the provisions of the Declaration of Principles on the issue of refugees in 1967.

In the 1996 Prime Minister election, Netanyahu was elected Prime Minister with a narrow margin. He proposed in the Government Policy Agenda in June 1996 that, "Israel opposes any kind of return rights of Arabians over the Israeli land on the West Bank of the Jordan River" (Yin, 1999, pp. 174-175). Netanyahu pointed out in his book A Durable Peace: Israel and Its Place Among the Nations, those Arabs who lived in the West Bank (Judea and Samaria) and Gaza currently were not refugees. When Israel intends to dismantle the remaining refugee camps, the Palestine Liberation Organization (PLO) and Arab countries strongly opposed against it. Netanyahu believed that they were hindering Arabia residents to resume normal life (Netanyahu, 2009, pp. 117-118).

On May 17, 1999, the Labor Party led by Ehud Barak won the election, the final negotiations officially started. At the opening ceremony of the first final negotiations on September 13, the Israeli negotiator David Levy proposed that Palestinian refugees should be placed in the host Arab countries. On January 26, 2000, Prime Minister Barak attended the commemoration of the massacre. At the meeting, he said that the return of Palestinian refugees should be after the founding of the Palestinian state (Yu, 2002, p. 81). On July 11, during the three party talks at Camp David among Palestine, Israel and the United States, although Barak proposed 
that Israel could make concessions on the territorial issue, he refused to accept any legal or moral responsibility on the refugee problem, neither to recognize the refugees' right to return. In the meeting, Israel vetoed the PLO's proposal to settle 360,000 refugees in three years in the west of the Jordan River area. Israel said the area could only allow 20,000 refugees per year (Liu, 2009), and agreed to allow 100,000 refugees to return for "family reunion".

In July 2000, Sharon, the President of the opposition party Likud, put forward that refugees could only be placed in Arab states where they were now living; Israel did not recognize the refugees' "right to return"; Israel should not be liable for any economic or moral responsibility for refugees (Tang, 2007, p. 106); the Knesset passed the refugee ban bill submitted by the Likud.

During the Taba Talks on January 21, 2001, Israel and Palestine gained an important breakthrough on refugees. The two sides announced that Israel did not assume legal responsibility on Palestinian refugees, and reached a consensus to solve problems (Arzt, 1996). However, Arafat overthrew the agreement the second days after the signing of the agreement, so "the agreement" had not been implemented.

During the 2001 election campaign, Sharon said Jerusalem and the refugee problem were non-negotiable. After winning the 2001 election, he insisted that Israel should not be responsible on refugees, and the refugees did not have the right to return the land of Israel. In 2004, in order to support the new Palestinian leader Abbas, Israel eased the requirements for Palestinians to enter Israel (Israel Ministry of Foreign Affairs, 2005), and Sharon also launched a "unilateral action plan" as well as the withdrawal of Gaza Strip, and gave up the jurisdiction of 820,000 registered refugees (Zhao, 2004).

In 2009, 2013 and 2015, Netanyahu won three consecutive victories, during his tenure, he repeatedly stressed that the Palestinians must recognize the Jewish's attribution of Israel, and requested Palestinian refugees to "give up the right to return". On November 23, 2014, the Israeli cabinet passed the "Jewish state bill" submitted by Netanyahu, which clearly defined Israel as a "Jewish state", and national rights belonged merely to Jewish citizens (Zhou, 2004). On May 28, 2015, when met with Israeli Foreign Affairs media reporters, Netanyahu claimed the support for the content of achieving a normalization of relations and the establishment of an independent Palestinian state in the Arab League peace initiative 13 years ago, but the country would not agree to accept refugees (Fan, 2015).

With the fermentation of the refugee crisis in Syria, in September 2015 the president of Likud and leader of Zionist Union Herzog asked the Likud government to accept refugees from Syria conflict. Netanyahu responded by saying that, "Israel is a small country, and has no population depth, we will not allow Israel to be flooded with illegal immigrants" (Beijing Morning News, 2015). In order to prevent the "illegal immigrants and terrorists" to infiltrate Israel, Israel began to build a border wall around the southern border, and strengthened border control.

\section{Common points of the Labor Party and the Likud's Palestinian Refugee Policies}

\section{Common Point in Policies}

Based on Palestinian refugee policy and diplomatic efforts of the Israeli government, during the administration of Israeli Labor Party leaders and Likud party leaders as Prime Ministers, we can find a plenty of similarities of the two parties on their stance on the refugee problem. They include the following five points:

First, Israel does not assume legal responsibility or moral responsibility for refugees, because the origin of the Palestinian Arab refugee problem was the Arab rejection of the UN partition resolution and the war which 
they declared against the State of Israel one day after its establishment. The responsibility is therefore theirs. Had the Arabs accepted the resolution, there would not have been any refugee problems (Israel Ministry of Foreign Affairs, 1977).

Second, Israel has insisted on resolving the issue of Palestinian refugees through negotiations with the Arab states. If the two sides cannot reach an agreement, they should put aside the issue and resolve it through long term negotiations. Since the Labor government in 1948, the Israeli government has stressed that the resettlement and repatriation of refugees should be based on a contractual basis between Arab and Israel rather than through the United Nations.

Third, Israel does not recognize the right of return of Palestinian refugees, and does not allow the refugees to return to the current Israeli land. Peres had stressed that, "If someone thinks that Israel will accept the right of return and commit suicide, the answer is, "No!"” (Israel Ministry of Foreign Affairs, 2001). Because the influx of millions of Palestinians into the State of Israel would threaten the existence of Israel as a Jewish state, obliterating its basic identity as the homeland of the Jewish people and a refuge for persecuted Jews worldwide. Consequently, the demand to "return" to Israel is nothing more than a euphemism for the demographic destruction of the Jewish state (Israel Ministry of Foreign Affairs, 2009).

Fourth, Israel believes that the best solution for the problem of Palestine refugees is to place them in Arabia. Netanyahu pointed out in his speech,

There is no reason why these people should be refugees after fifty years. I believe that once the political motivation behind their remaining refugees is abandoned, it should be possible to find them permanent dwellings fairly quickly, as has been done in Jordan. If there is a political intention to continue the refugee problem, then it will continue, also in the areas under P.A. jurisdiction. (Israel Ministry of Foreign Affairs, 1997)

Fifth, Israel adheres to the principle of mutual compensation. Israel put forward, since 1948, Arab states implement persecution and expulsion on Jews in their countries; Israel integrated the uprooted Jews into its society as full-fledged citizens, but the Arab states have made no effort to solve the problem of the Palestinian Arab refugees. Instead, their goal is to maintain their dismal conditions in order to use them as a political weapon in their struggle against Israel (Israel Ministry of Foreign Affairs, 1992b). Jewish refugees should also ask for compensation from the Arab states, which is as reasonable as that the Arab asked Israel for compensation for Palestinian refugees.

\section{The Reasons for the Policy Similarity}

Jewish nation state. The Israeli political scientist Aryeh Naor pointed out that the Zionists "they wanted to create a Jewish state, a democratic state, and a state that would be located in the historical homeland of the Jewish people - the land of Israel — which technically included all the Palestine from the Mediterranean Sea to the Jordan River" (Friedman, 2012, p. 253). This indicates that the Jewish nature of State of Israel has been determined from the founding, which is very important for the Jews. The political issue of the population has always had a high popularity in Israel. According to the Israel Times, data shows that about 6.8 million Palestinians and 6.1 million Jews are living in the West of Jordan River. In accordance with the current rate of growth of the Palestinians, in 2020, the population of the Arabia Palestinian in this area will reach 7.14 million, while the Jews will be only 6.87 million (Israel Times, 2015). Due to the gap in natural growth rate, Israel has faced a huge risk that Jews may become a minority, which is the main reason for Israel to reject more Palestinians to enter the country. 
Peres once said, "If you accept the refugees to return to Israel, it will eliminate Israel's Jewish national characteristics, so that the Jews turn into a minority of the population... No Israeli government would agree to a strategy that would undermine our national identity" (Peres, 1994, p.154). Sharon also mentioned "No right of return for Palestinian refugees" in the cabinet meeting, as "critical issues which are so essential to the existence of the State of Israel" (Israel Ministry of Foreign Affairs, 2004). As Al-Kaddafi himself said, "at that time (that is, after the return of the refugees), Israel will no longer exist... If they accept it, then Israel will be brought to an end" (Netanyahu, 2009, p. 188). In order to prevent Israel from turning into a country where Jews are the minority, the two parties will not allow a large number of Palestinian refugees return to Israel, it is impossible to compromise on the key issue of the nature of the country.

Homeland security. From the beginning of the founding of the country, Israel has been in a hostile environment. From the war to the terrorist attacks, the survival and security of Israel is always the main problem and consideration of the government. Accordingly, when it comes to the issue of Palestinian refugees, for the sake of homeland security, and to prevent the entry of terrorists, the Israeli government rarely make decisions to allow Palestinian refugees to return to Israel. Even if there were some refugees to return to Israel in the way of "family reunion", they also need to go through multiple approval, as well as strict inspection, in order to prevent terrorists from entering Israel in this way. About Barak's policy that allowed Palestinians to return to the West Bank, Sharon said, if the return of Palestinian refugees only limited to returning from refugee camps to their previous habitants, it must result in new tensions due to anger, so if you wanted to ensure the Israel's security, you could not solve the refugee problem in Israel, the tragedy caused by the Arabs themselves should not be replaced with a new tragedy (Sharon, n.d.).

This fear of the Israeli government is not unreasonable. In the refugee camp, Palestinians are more vulnerable to political power and religious extremism and their guides. The refugee camp has become a fertile ground for Palestinian extremist groups to recruit new members. Children that grew up in a refugee camp have been told in their childhood that, it is Israel's war of aggression that causes their plight now, and the only way out of this state is to return to Haifa and Jaffa, and "throw Israel back into the sea". In addition, the school of United Nations Refugee Relief Agency was also used to instill Jihad ideology and extreme violent activities, for example, Hamas' former Interior Minister Sayaman taught for 20 years at the school of United Nations Refugee Relief Agency, teaching students the concept of extremism and means for violent attacks. In 2004, the Hamas leaders Abdel Aziz Rantisi, a eliminating target of the Sharon government, graduated from the school of United Nations Refugee Relief Agency; in August 2002, a Hamas member, Nidal Nazar, admitted that he had repeatedly use the ambulance of United Nations Refugee Relief Agency to transport weapons and ammunition to Hamas, and tipped off for the extremists (Romirowsky, 2007). Similarly, the extremists use refugee asylum process to sneak into the target area to launch attacks, which has become common.

The influence of the political party system. Coalition government is the basic form of the Israeli government. The political party that wins the election needs to draw on other parties to obtain the necessary seats. In the process of negotiations to form the cabinet, a large party often needs to make some concessions in order to appeal a small party. During the administration, in face of disagreements, small party is also likely to threat to quit the coalition government as a hostage, forcing the big party to agree with its views.

In many small parties in Israel, religious parties are often the most influential for the ruling party. Due to the special status of Judaism in Israel, religious parties are often the object of elected party to build a coalition government. The Likud and the Labor Party are asked to meet some of the requirements from religious parties 
to gain religious support, hence a tough stance of religious parties on the issue of refugees will naturally affect them.

In addition to the religious parties, the opposition of other small right-wing parties on the admission of refugees will also impact on the ruling party, for example, the National Union called for talks with the Arab states to transfer Palestinian refugees to Arab states, in order to maintain a Jewish state property of Israel; the Tami party in foreign policy advocates for the annexation of the West Bank and transferring the Palestinians to Arab states (Feng, 2010, p. 197, p. 206).

Cognitive and cultural factors. Cognitive psychology points out that the cognition of decision makers is the basis of political behavior, and many international conflicts are not produced in the opposition of interests, but rooted in different understanding patterns (Ben-Dor, 1983, p. 187). The "Disaster memory", "Diaspora" and the isolation from international community after the founding of the country have resulted in "Jewish Insular Psychology" in dealing with the outside world (Feng, 2010, p. 7). In this culture, Israel is showing greater sensitivity and insecurity in the reality that the Arab-Israeli conflict could not achieve reconciliation for a long time, and it is more prone to have excessive response to terrorist attacks, kidnapping, immigration and other extremist events. In the drive of national culture, in the security aspects, Israeli policymakers are also more likely to be influenced by cognitive consistency, evoked set and the historical burden of psychological mechanism, taking a tough attitude in the matter of security affairs in foreign policy.

Specific to the refugee problem, affected by the "Insular Psychology" and the psychological mechanism mentioned above, Israel believes that national refugees" "right to return", reiterated by Arab states, is a plot of Arab states to destroy State of Israel, because on one hand, the return of refugees can gain advantage in population, resulting in the gradual elimination of Israel's "Jewish" nature; on the other hand, it can incite refugees on extreme nationalism and religious extremist ideas of terrorism in Israel, and utilize the refugees' return to carry out the "jihad" in Israel. Netanyahu believes that

If the Arab countries want to achieve the plot of eradication of Israel, the refugees would have to maintain the identity of the refugees, always being unfortunate, and will be permanently displaced. For the Palestine Liberation Organization, the refugee camp is not only a good place for political propaganda, but also the fertile ground for recruitment of new "soldiers". The group is more willing to resort to violence, in order to ensure the camps always exist. (Netanyahu, 2009, p. 116)

This fully illustrates the direct role of the perception on refugees of Israeli policy makers in Israel's policy towards the Palestinian refugees.

The impact of the United States. The United States has a special relationship with Israel. As a result, the United States plays an important role in Israeli foreign policy. Since 1960s when the United States President Johnson built a "quasi-alliance" between Israel and the US (Sun, 2001, 2003, 2005), the US has been supportive to Israeli policy towards Palestine in the majority of cases. In terms of diplomacy, it particularly took care of the interests of Israel. But for the sake of promoting two sides to reach an agreement as well as a realization of peace, and also adding to the diplomatic achievements of this government, the US government would also impose pressure on Israel to compromise on some issues of Palestine in order to reach an agreement.

However, in the refugee issue, the position of the United States is much more moderate compared with Jewish settlements, territorial boundaries and other issues. In exception that the Truman administration once 
proposed a 10,000 refugees' accommodation request to Israel, the other presidents did not put pressure on Israel for the Palestinian refugees specifically, but instead, claimed together with Israel to advocate that refugees should be resettled in the Arab states. In 1950 the United States government put forward the residential housing construction for the refugees in the way of economic assistance; in 1955 the "Johnson plan" proposed that through a large amount of financial aid to Arab states in exchange for support on resettlement of Palestinian refugees in their territory, and drafted an on-the-spot investigation report to settle part of the refugees in Egypt's Sinai Peninsula (Jiang, 2000, p. 27). In the Israeli-Palestinian Camp David talks, the United States also proposed $\$ 300$ million compensation for Palestinian refugees with settlements in their current habitats; after the failure of the talks, Clinton once again proposed the "right of return" of refugees should be confined in the future State of Palestine. The United States basically has similar position with Israel's on the issue of refugees; the diplomatic support from the US ensures a strong guarantee for Israel's tough policy on the Palestinian refugees.

\section{The Difference between Labor Party and Likud on Palestinian Refugee Policy}

\section{Policy Differences}

As two parties with different voter foundation and ideology, the Labor Party and the Likud still have some differences in the Palestinian refugee policy; these differences also fit the traditional concept and image of "right wings" and "left wings" parties.

First of all, because the Likud adheres to the Jewish attribute of Israel more than the Labor Party, it has a tougher stance that does not allow the return of refugees and does not recognize the "right to return". In most Arab-Israeli negotiations which the Likud government participated in, Israel used vague references on the refugee problem, but did not make any commitment to allow refugees to enter the territory of Israel. In comparison, the Labor Party Prime Minister Ben Gurion, Rabin, Barak all had to make substantial concessions to Palestine.

Secondly, on the question of compensation, although both parties think Israel does not assume legal responsibility on Palestinian refugees, the Labor Party is more prone to compromise on the issue of compensation, while the Likud emphasizes on the "mutual compensation" of Israeli and Palestinian refugees.

Thirdly, in terms of the construction of the West Bank Barrier, the Likud has more firm attitude than the Labor Party, by this way, they want to cut off illegal immigrants of the refugees. The original complete plan of the wall was proposed and built by the Sharon government led by the Likud Party. In 2015 the Labor Party leader Herzog proposed that Israel should accept the Middle East refugees. Likud Prime Minister Netanyahu's response was a stricter control of the boundary, and an extension of the wall at the border between Israel and Jordan to prevent the inflow of refugees and terrorist infiltration.

\section{The Reasons for the Policy Differences}

Factions in Zionist movement. The worldwide Zionist movement is the origin of the founding of Israel. Jews of different countries, different class, and different ideologies have formed different camps, in an effort to establish a Jewish state. The diversity, differences and complexity of Zionist movement have become the original form of the Israeli political party (Wang, 2014, p. 38).

From the perspective of ideological differences, many political parties in the Zionism can be divided into 
three factions: the Labor Party, revisionist faction and religious parties. The Labor Zionist party is a founder of the majority of Jewish settlements movement and the Israeli Labor Party; revisionist faction represents the Jewish bourgeoisie interests; and the main predecessors of the Likud party before the merge all belong to the revisionism, this fraction has opposite value against the Labor Party.

In 1948, after the Palestinian refugee problem, the Likud's predecessor Herut regarded the Palestinian refugees as Israel's enemies under the guidance of its consistent emphasis on nationalism, because they did not recognize the legitimacy of the Zionist movement, even helped Arab countries to invade in new State of Israel. The basic ideology and the guiding ideology inherited from the traditional Zionism movement have led to the difference of Labor Party and the Likud in specific foreign policy.

Major voter groups. According to the different diasporas, Jews can be divided into Western Jews (Ashkenazi Jews), Oriental Jews and Sephardi Jews; they are from Europe, West Asia and North Africa and the Iberian Peninsula countries respectively. Because the Oriental Jews and Sephardi Jews are more similar, after they were expelled, most Sephardi Jews lived in West Asia and North Africa, so in many studies, Sephardi and Oriental Jews are categorized into the same group.

Since 1960s the Israeli election has basically formed such a pattern: $2 / 3$ of the Labor Party's votes are from the Western Jews, and 2/3 of Likud's votes are from the Oriental Jews (Arian, 1989, p. 155). Because most Eastern Jews are from Arab states, they suffered persecution and expulsion in the original country and become refugees, so they have a tougher attitude to Arab states, and this is in accordance with Likud's hardline policies. During the period of Likud administration, it has repeatedly emphasized on the rights of the Jewish refugees during the Middle East wars, and stressed that the solution of the refugee problem should not only be concerned with the Palestinian refugees, Jewish refugees that had been expelled from Arab states must also have the right to demand compensation (Knesset, 2015).

Oriental Jews are the ethnic group that most fiercely opposed to the Palestinian refugees' "right to return", which is not only affected by the historical experience; in real life, the competition from the Arabs is also an important reason. The level of education of Sephardi people is relatively low, so in the labor market, their competitiveness is weaker than Ashkenazi Jews. They are mostly engaged in labor intensive jobs. The competition with Arabs in the employment opportunities has made the Oriental Jews more exclusive to Arabs, and more strongly against the return of Palestinian refugees. By contrast, Western Jews that work in the relatively high-end industry rarely face the pressure, if the government allows entry of refugees, the impact on the practical interests of this ethnic group is far less than the Oriental Jews. Therefore, with the Ashkenazi Jews as the main group of voters, the Labor government can adopt more flexible refugee policy.

National interests and party interests in different periods. When making foreign policy, both the Labor Party and the Likud government will not only consider the factors of safeguarding national security and promoting the peace process in the Middle East, but also consider the consolidation in their ruling position in the country.

The most direct and critical problem faced by the Labor government in the founding of the country is to solve the survival crisis, resist foreign enemies, develop economy and absorb Jewish refugees in face of domestic trouble and foreign invasion, and consolidate the Jewish state. At that time, the Labor Party had the absolute leadership in the country, and no other party or interest group could pose a challenge to the Labor 
Party's position, so before 1977 the Labor Party government was with greater autonomy in dealing with the issue of Palestinian refugees. After the party's leading position is subject to the challenge of the right wing party, in order to win the votes, the Labor Party needed to show different foreign policies with its competitors, to win the support of the left-wing voters. The Labor government had greatly encouraged the Jewish voters that in support of peace by promoting the peace process in the Middle East, and the negotiations on refugees also progressed smoothly. However, the Labor Party government's policy to compromise to Palestine angered right-wing voters. The appeasement of Palestine on terrorism also made the people of Israel seek more secure policies. Although in 1999 Barak again led the Labor Party to win the election, his unprecedented concessions to Arafat during the talks at Camp David failed to obtain the corresponding commitments of Palestine in exchange, combined with the heavy casualties of the Jews in the second Intifada movement, the Labor government could not consolidate the ruling status in politics, and fell in decline step by step.

The first Likud victory was thanks to Oriental Jews' support, so that in the early stage of ruling, in pursuing the party's ruling idea, the Likud party also needed to cater to the needs of Sephardi people by pursing tough policy of zero negotiation on refugee issues, in order to prevent greater competition caused by Palestinians over Oriental Jews. Since 1990s, the peace process in the Middle East has made some progress under the leadership of the Labor Party, but the domestic security situation still wasn't improved. At this time, Netanyahu's slogan of "security for peace" had gained more support in Israel. The same situation happened in 2001 after the intifada; Sharon's tough foreign policy became more popular: in any case, refugees were not allowed to return Israel, and ended any contact with Palestinian refugees and terrorists in Gaza. To a certain extent, these policies had promoted the stability of the domestic security situation. After Netanyahu's last three terms, the slumped Israeli domestic economy, the escalation of the Palestinian Israeli conflict, Israel's growing international isolation, and that several times to restart peace talks were fruitless, prompted the Netanyahu administration to deviate more to the right wing, stressing on the Jewish attributes of Israel by refusing the return of refugees and launching the "Jewish state act". The Likud won again in the 2015 general election, which showed that this strong policy obviously agrees with Jewish voters' demand.

\section{Prospect Analysis}

At present, a new round of conflicts will make Israel to face a more politically Islamic Middle East on one hand, and the threat of religious extremist ideas on Israel will not be weakened; on the other hand, the increase of attention and number of hot issues in the Middle East significantly decreased the importance and the degree of Palestine-Israel conflict in the Middle East, which provides opportunities for Israel to strive for support from more moderate Arab countries, and to ease regional status, reduce regional isolation, and alleviate international pressure. Israel is likely to have a greater advantage over the Israeli Palestinian peace talks due to the ease of international pressure.

Judging from the current situation in the Middle East, the escalation of the conflict between the two sides leaves barely any hope to restart the peace talks between the two sides. In the short term, the two sides will not agree on the settlement of the refugee problem. But the situation in the Middle East is complex and changeable, and prone to be influenced by the policies of foreign powers, for example, the new 2016 president of the United States may urge the Israeli Palestinian peace talks at the beginning of his administration, to provide a chance 
for a reconciliation for both sides, so in the long run, between Palestine and Israel, it is still likely that the two sides can have a common solution to the refugee problem.

In July 2003, the Palestinian political scientist Khalil Shikaki launched a public opinion survey on refugees. It indicated that, more than $90 \%$ Palestinian refugees did not really want to go back to the land of Israel before the war of 1967. Most people were willing to settle in their current habitats, and accept compensation to replace the right to return. When the investigators told them that the villages before the war in 1948 they had once live had no longer existed, the ratio of those not willing to return was elevated (Shikaki, 2003). This survey results show that it is actually possible for the Palestinian side to give up the refugee right to return (Korobkin \& Zasloff, 2005), the two sides can seek consensus on the issue of refugees through compensation and other ways. In 2007, during the Arab League summit, Arab states also proposed to "fairly solve the fate of Palestinian refugees", because many Palestinian refugees were willing to obtain compensation and stayed in their country of residence; the two sides only needed to explore how to settle the refugees who insisted to return to Israel and part of the territory of State of Palestine in the negotiations (Primakov, 2014).

With regard to the solution to the problem of Palestinian refugees, Israel has always stressed on the "local integration" as the best way to solve the problem of refugees, in addition to this, the remaining refugees can return to the future State of Palestine. In fact, both sides understand that Palestinian refugees cannot scale into Israel. Palestinian tough stance on the refugee problem in most cases was only to increase its own bargaining chips. With a comparison on both sides' proposals, a mutually acceptable agreement in theory should include the following parts: first, a certain number of refugees, especially those Palestinians have residence in the current living country shall be placed in Arab states; second, the State of Palestine is finally established under the Palestinian Israeli agreement, giving refugees nationality of State of Palestine, and most refugees settled in State of Palestine; third, a small amount of refugees return to the land of Israel after the war of 1948 as a "family reunion" mode through the application approved by the Israeli government. The author believes that if an opportunity appears that can promote the interests exchange of the two sides at the negotiating table in the future, the refugee problem may be resolved in the above three channels.

\section{Conclusion}

As the most influential parities with the longest ruling periods in the history of Israel, the Labor Party and the Likud party took similar policies on the issue of Palestinian refugees during their administrations, but there are also some differences. With respect to the denial of Israeli responsibility on the formation of Palestinian refugees, adherence to the long-term solution to the refugee problem through negotiations, refusing to recognize the refugees' right to return, support for the refugees to stay in the country of residence, insistence on the principle of mutual compensation and so on, the Labor Party and the Likud party have some coherence and consistency in their refugee policies, which is affected by the domestic and foreign factors they face. Because Israel must adhere to Jewish property and safeguard national security, both Labor and Likud must put the two core elements in the first place in formulating foreign policy, to prevent the return of refugees from largely increasing domestic Arabia population, threatening the Jewish state property; also to guard the country against terrorist attacks and terrorist penetration into Israel with the identity of refugees. In addition, the Israeli multi-party parliamentary system determines the ruling party will be influenced by a small party with the 
hardline policies; the traditional "Insular Psychology" of Jewish nation and other psychological factors will also aggravate the Israeli public insecurity. They are cautious about any factors that can cause instability, and thus reject the return of refugees. Diplomatic support from the United States on return of refugees and refugee problems also provide a guarantee for Israel's hardline policies.

In different periods of the two parties' administration, the two sides have made different progress in the settlement of the issue of refugees. During the Labor Party's ruling, the Israeli and Palestinian peace talks in the refugee problem could often make substantial progress; while when the Likud leaders were in office, they made few concessions and commitments to solve the problem of the Palestinian refugees. The Likud is often showing an image of non-compromise and non-negotiable on the issue of refugees, with stronger stick to the Jewish state property, no economic compensation to Palestinian refugees, and advocacy on the construction of the isolation zone to block illegal entry channels for refugees. Due to the different factions in the Zionist movement, the Labor Party and the Likud have always had different political traditions; and the voter foundations of the two parties are not the same: the main voter group of the Labor Party is the Ashkenazi Jews, who are not directly affected by the Arabs in the employment competition, so in dealing with the return of refugees, the Labor Party has greater flexibility than the Likud. In addition, the domestic and foreign environments faced by Israel's ruling party at different times are not the same; in a joint role of these factors, the two parties' refugee policy must be different.

Overall, the Palestinian refugee problem is one of the most difficult issue to be resolved in the Israeli Palestinian peace talks; because for the Israeli left and right wing political parties, to prevent the entry of Palestinian refugees has absolute necessity. The reason for a bipartisan hardline stance is obvious. But different level of pressure from the domestic public makes the Labor Party relatively prone to compromise and becomes the left wing. In the Middle East peace process, the Israeli government led by the Labor Party is more prone to make substantive commitments on refugees than the Likud government.

Nowadays, with further escalation of the conflict in the Middle East region and regional situation becoming more complicated, the attention on Palestinian-Israeli conflict is declining, which indicates that the international pressure Israel faces in solving the refugee problem decreases, and it will be more difficult for the country to compromise on refugee issue. In the long term, if the two sides can again restart peace talks, and include the Palestinian refugee problem in the agenda, and make a full exchange of interests, the refugee problem may be resolved in three ways: some refugees are settled in the country of residence, most of them come back to the future State of Palestine recognized by Israel, a few return to Israel via a "family reunion".

\section{References}

Arian, A. (1989). Politics in Israel: The second generation. Chatham, NJ: Chatham House Publishers.

Arzt, D. (1996). Negotiating the last taboo: The Palestinian refugees. FOFOGNET Digest, January, 29-31.

Beijing Morning News. (2015, September 8). Israel rejects neighboring refugees.

Ben-Dor, G. (1983). State and conflict in the Middle East. New York: Praeger Publishers.

Fan, X. L. (2015). Netanyahu expressed support for the basic concept of the Arabia peace initiative. Xinhua News, May 29. Retrieved from http://news.xinhuanet.com/world/2015-05/29/c_1115443506.htm

Feng, J. H. (2010). Jewish culture and Israeli sociopolitical development. Beijing: Social Sciences Academic Press.

Friedman, T. (2012). From Beirut to Jerusalem, London: Picador.

Israel Ministry of Foreign Affairs. (1977). 55 statement to the United Nations General Assembly by foreign minister Dayan-10 October 1977.

Retrieved

October

10 ,

1977,

from 
http://mfa.gov.il/MFA/ForeignPolicy/MFADocuments/Yearbook3/Pages/55\%20Statement\%20to\%20the\%20United\%20Nati ons\%20General\%20Assembl.aspx

Israel Ministry of Foreign Affairs. (1978). 178 statement to the Knesset by Foreign Minister Dayan on the Leeds Castle $\begin{array}{lllllll}\text { Conference, } & 24 & \text { July } & \text { 1978. } & \text { Retrieved } & \text { July } & 24,\end{array}$ http://mfa.gov.il/MFA/ForeignPolicy/MFADocuments/Yearbook3/Pages/178\%20Statement\%20to\%20the\%20Knesset\%20b y\%20Foreign\%20Minister\%20D.aspx

Israel Ministry of Foreign Affairs. (1992a). The Middle East refugees-Jan-92. Retrieved January 27, 1992, from http://mfa.gov.il/MFA/ForeignPolicy/Peace/MFADocuments/Pages/THE\%20MIDDLE\%20EAST\%20REFUGEES\%20-\%20 Jan-92.aspx

Israel Ministry of Foreign Affairs. (1992b). The multilateral talks-structure and progress-update-24-Nov-92. Retrieved November 24, 1992, from http://mfa.gov.il/MFA/ForeignPolicy/Peace/MFADocuments/Pages/THE\%20MULTILATERAL\%20TALKS -\%20STRUCTURE\%20AND\%20PROGRESS\%20-\%20U.aspx

Israel Ministry of Foreign Affairs. (1997). Speech by PM Netanyahu to Israeli Editors Association-November-27-1997. Retrieved November 27, 1997, from http://mfa.gov.il/MFA/MFA-Archive/19961997/Pages/Speech\%20by\%20PM\%20Netanyahu\%20 to\%20Israeli\%20Editors-\% 20Associa.aspx

Israel Ministry of Foreign Affairs. (2001). FM Peres to PES participants-Arafat erred in rejecting Clinton proposals and deciding to open fire. Retrieved May 8, 2001, from http://mfa.gov.il/MFA/PressRoom/2001/Pages/FM\%20Peres\%20to\%20PES\% 20Participants-\%20Arafat\%20erred\%20in\%20reje.aspx

Israel Ministry of Foreign Affairs. (2004). Cabinet Communique. Retrieved April 18, 2004, from http://mfa.gov.il/MFA/PressRoom/2004/Pages/Cabinet\%20Communique\%2018-Apr-2004.aspx

Israel Ministry of Foreign Affairs. (2005). Guide to the peace progress-Israeli disengagement plan. Retrieved May 31, 2005, from http://www.mfa.gov.il/MFA/Peace+Process/Guide+to+the+Peace+Process/Israeli+Disengagement+Plan+31-May-2005.htm

Israel Ministry of Foreign Affairs. (2009). Israel, the conflict and peace: Answers to Frequently asked questions: Refugees. $\begin{array}{llll}\text { Retrieved December 23, from } & \text { 2009, }\end{array}$ http://mfa.gov.il/MFA/ForeignPolicy/FAQ/Pages/FAQ_Peace_process_with_Palestinians_Dec_2009.aspx

Israel Times. (2015, November 22). The population births of Jewish Jews and Arabians are at the same level.

Jiang, D. D. (2000). They are still very far away from home: The tough refugee problem in peace negotiation. World Affairs, 17 , 27.

Knesset. (2015). Knesset marks flight of Jews from Arab lands; Speaker Edelstein: "When we speak of displacement and refugees, this cannot come from just one side”. Retrieved December 9, 2015, from http://www.knesset.gov.il/spokesman/eng/PR_eng.asp?PRID=11809

Korobkin, R. B., \& Zasloff, J. (2005). Roadblocks to the roadmap: A negotiation theory perspective on the Israeli-Palestinian conflict after Yasser Arafat. Yale Journal of International Law, 30, 27.

Liu, Z. Y. (2009). Israel's security strategy in the Israeli Palestinian conflicts. Academia Bimestris, 3, 171.

Maslha, N. (1996). Israeli plans to resettle the Palestinian refugees 1948-1972. Publisher: Palestinian Diaspora \& Refugee Centre (SHAML).

Netanyahu, B. (2009). A durable peace: Israel and its place among the nations (T. Z. W. Shawen, Trans.). Beijing: World Knowledge Press.

Peres, S. (1994). The new Middle East (Xinhua Press, Trans.). Beijing: Xinhua Press.

Primakov, Y. (2014). The secret: the front and behind the scenes of the Middle East (the second half of the $20^{\text {th }}$ Century-21 Century) (C. Z. Li, Trans.). Beijing: China Translation Publishing Co..

Romirowsky, A. (2007, November 28). How the U.N. supports Hamas. Jewish Policy Center.

Sharon, A. (n.d.). Arab Peace Ambush. Retrieved from http://www.likudusa.com/articles/sharon2.htm

Shikaki, K. (2003). Palestinian refugees: Preferences in a final Israeli-Palestinian Peace Agreement. Luncheon Discussion. Retrieved July 16, 2003, from http://www.brookings.edu/fp/saban/events/20030716.pdf

Sun, D. G. (2003). On the foundation of the special relationship between Israel and the US during Johnson administration. World Ethno-National Studies, 6, 12-21.

Sun, D. G. (2005). Quasi alliance phenomenon in international relations: The Case of America's relations with Israel during Johnson administration. West Asia and Africa, 4, 26-30.

Sun, D. G. (2011). On the "Quasi Alliance" strategy. World Economics and Politics, 2, 55-79.

Tang, B. C. (2007). The turbulent Middle East after Iraq War. Beijing: The Contemporary World Press. 
United Nations High Commissioner for Refugees. (2014). Report on World at War: UNHCR Global Trends Forced Displacement in 2014.

UNRWA. (n.d.). Who are Palestine refugees? Where do Palestine refugees live? Retrieved from http://www.unrwa.org/palestine-refugees

Wang, S. M. (2015). The problem of Palestine refugees in Lebanon. Journal of World Peoples Studies, 3, 84.

Wang, Y. M. (2014). Party politics in Israel. Beijing: The People's Press.

Xu, X., \& Gong, S. P. (1998). History of peace negotiations in the Middle East 1913-1995, Beijing: China Social Sciences Press.

Ye, G. L. (1998). Various factions and different ideas in the peace process of Israel parties. The Contemporary World, 2, 24.

Yin, C. J. (Ed.). (1999). One hundred years of the Middle East problem. Beijing: Xinhua Publishing House.

Yu,W. Q. (2002). A historical study on the problem of Palestinian refugees. Doctoral Dissertation of Northwestern University.

Zhao, G. Z. (2004). Some comments on Israeli prime minister Ariel Sharon's “Unilateral Action Plan". Peace and Development, $3,39$.

Zhou, R. (2014, December 4). The "Jewish State" bill caused political crisis. Wenhui Daily. 